\title{
Corruption and FDI in OIC Countries
}

\author{
*1Ahmad Jafari Samimi, 2Maryam Monfared \\ 1,2Islamic Azad University, Firoozkuh Branch, Firoozkuh, Iran \\ *jafarisa@yahoo.com
}

\begin{abstract}
The purpose of the present paper is to investigate the impact of corruption on foreign direct investment revenues in OIC countries. To do so, we have concentrated on a sample of 16 countries for which the necessary data were available for the period 2002-2008. We have used panel regression analysis. Our empirical results support that openness and Gross domestic product (GDP) have positive impact and inflation and corruption have negative impact on FDI in OIC countries.
\end{abstract}

Keywords: Foreign Direct Investment (FDI), corruption, OIC countries, panel regression.

\section{Introduction}

Today, many countries due to inadequate domestic resources for investment, inclined to absorb foreign capital have found. On the other hand, foreign investors, especially multinational companies, to promote competitiveness and investment more profit are inclinedto prone and advantageous regions. Also in the past two decades with promotion of technology, possibility of capital transmission has increased significantly. Natural result of the above factors is the growths of foreign capitalize in different countries, both developed and under development. Attract foreign direct investment to any country is not subject to the condition of entry liberalization and foreign investment incentives of financial donation to the foreign firm ,one of the important issues in strategies of attract foreign investment is reducing risks of country. One of these risks is the host country political risks that the corruption is one of those risks. Unusual questions that are raised here is whether the corruption to attract FDI is good or bad? Especially, if corruption levels FDI, increased or decreased or not?

The debate on the adverse effects of the level of corruption on FDI inflows has been analyzed in context of the costs of doing business. Since foreign investors have to pay extra costs in the form of bribes in order to get licenses or government permits to conduct investment, corruption raises the costs of investment. Such additional costs decrease the expected profitability of investment and so corruption is generally viewed as a tax on profits (Bardhan, 1997). Moreover, corruption increases uncertainty because corruption agreements are not enforceable in the courts of law. Foreign investors would tend to avoid investing in countries with high levels of corruption. Some studies have argued that corruption may have a positive effect on the economy: corruption, with reduction of paperwork, has attracted FDI so reduce once taxes and controls of non-rational capital. Houston (2007) studied the effects of corruption on a country's economic performance and found that corruption has positive effects on economic growth in countries with a weak rule of law, while it has negative effects in countries with sound institutions. Also, Swaleheen and Stansel (2007) concluded that corruption enhances economic growth in countries with high economic freedom, while it hinders economic Growth in countries with low economic freedom.

\section{Review of Literature}

In this section, we review some major recent studies of relationship between corruption and FDI. However, the main conclusion of most studies supported the positive impact of CPI on tax revenue of developed as compared to developing countries. Abed and Davoodi (2000) use a cross-sectional as well as a panel data analysis to examine the effects of levels of corruption on per capita FDI inflows to transition economies. They found that countries with a low level of corruption attract more per capita FDI. Wei 
(2000) studied the effect of corruption on foreign direct investment. The sample covers bilateral investment from twelve source countries to 45 host countries. There are two central findings. First, a rise in either the tax rate on multinational firms or the corruption level in a host country reduced inward foreign direct investment. In benchmark estimation, an increase in the corruption level from that of Singapore to that of Mexico would have the same negative effect on inward FDI as raising the tax rate by fifty percentage points. Second, American investors were averse to Corruption in host countries, but not necessarily more so than average OECD investors. This is a cross-sectional study relying on data for the year 1993.

Akcay (2001) failed to find evidence of a negative relationship between FDI and corruption. He concluded that the most significant determinants of FDI are market size, corporate tax rates, labor costs, and openness. Habib and Zurawicki (2002) also supported the negative impact of corruption. Their analysis showed that foreign investors generally avoid corruption because it is considered wrong and can create operational inefficiencies. Smarzynska and Wei (2002) used a firm-level data set from transition economies to investigate the effects of corruption in terms of firms' decision not to enter a particular market, rather than in terms of reduced bilateral investment flows. Larrain and Tavares (2004) estimated the impact of FDI inflows on corruption at the country level, taking into account the issue of reverse causation. They found that FDI as a share of GDP is significantly associated with lower corruption levels, irrespective of import intensity levels. The quantitative impact of FDI on corruption appears to be of the same order of magnitude as that of per capita GDP. Mathur (2007) found that corruption perception played a big role in investors' decision of where to invest.

Zhou (2007) concluded that the overall effect of corruption is significantly negative on the Probability of both FDI inflows and stocks being present, which indicates the dominant effect of non-discriminatory corruption in determining MNEs' FDI decisions. His estimation results showed that the effects of corruption on the short term (measured by FDI inflows) and long-term (measured by FDI stocks) decisions are not exactly the same, therefore when studying the effect of corruption we need to specify whether it is the short-term or long-term investment choices we are interested in. Al-Sadig (2009) used a cross-sectional as well as a panel data analysis to examine the effects of levels of corruption on FDI for 117 countries over the period 1984-2004, He found that corruption has a negative effect on FDI, for all countries. Kardesler (2009) find that corruption has a negative effect on FDI, contrary to the Efficient grease Hypothesis, in the case of the EU region. This finding implies that investors are not eager to make FDI in economies that experience high levels of corruption in the EU region. Kyung (2009) studied the effect of corruption on FDI and concluded that corruption is bad for economy. However, some data implied that the economic effects of corruption may depend on initial conditions, such as given level of corruption. In this paper he showed that, the effects of corruption on FDI are same in different groups of countries. The hypothesis is that while corruption decreases FDI level in highly corrupted countries, or developed countries; they have no correlation in low corrupted countries, or developing countries.

\section{Model, data, and estimation methodology}

This article employs panel data for 16 countries over the period 2002-2008. All countries (OIC) for which data are available over this period are included in this study. In our study, we will use of panel data methods to estimate data. The FDI data is in terms of USA dollars and obtained from the World Bank's World Development Indicators (WDI, 2009). Our independent variable include Openness of the economy (computed as export plus import as a share of GDP), GDP and Inflation come from the World Bank's World Development Indicators (WDI, 2009). Comparison of these data in table (1) indicates that measure of average GDP, average Openness and FDI in OIC countries. The dependent variable is FDI inflows. The key explanatory variable is the corruption level in the host country as measured by the International Country Risk Guide (ICRG) corruption index. Corruption is an index scaled from 6 (highly corrupt) to 0 (highly clean). 


\section{Results}

Comparison of corruption and Average of some Variables in table (1) \& (2) shows that Jordan, Turkey and Tunisia are cleaner than other selected countries. As can be seen some recent and potential members have relatively bad scores. As it shown in Table (2) \& Fig (1) the average of Foreign Direct Investment and GDP in Turkey is more than the other countries. Turkey has a low corruption and high foreign direct investment and GDP among selected countries.

Table 1: Corruption Index in Selected OIC Countries, 2008

\begin{tabular}{ccc}
\hline Rank & Country & Score \\
\hline 85 & Albania & 3.4 \\
92 & Algeria & 3.2 \\
147 & Bangladesh & 2 \\
151 & Cote & 2.1 \\
115 & Egypt & 2.8 \\
141 & Iran & 2.3 \\
47 & Jordan & 5.1 \\
145 & Kazakhstan & 2.2 \\
80 & Morocco & 3.5 \\
121 & Nigeria & 2.2 \\
134 & Pakistan & 2.5 \\
85 & Senegal & 3.4 \\
80 & Thailand & 3.5 \\
62 & Tunisia & 4.4 \\
58 & Turkey & 4.6 \\
126 & Uganda & 2.6 \\
\hline
\end{tabular}

Source: Transparency International, Global Corruption Report 2009

Table 2: Average of Variables in Selected OIC countries (million dollars)

\begin{tabular}{lcc}
\hline \multicolumn{1}{c}{ Country } & $\begin{array}{c}\text { Average Foreign Direct } \\
\text { Investment }\end{array}$ & Average GDP \\
\hline Albania & 406 & 8,411 \\
Algeria & 1,395 & 105,198 \\
Bangladesh & 563 & 60,885 \\
Cote & 309 & 16,806 \\
Egypt & 5,518 & 105,728 \\
Iran & 2,469 & 207,743 \\
Jordan & 1,814 & 14,270 \\
Kazakhstan & 6,284 & 67,864 \\
Morocco & 1,777 & 62,351 \\
Nigeria & 4,440 & 120,968 \\
Pakistan & 2,854 & 113,956 \\
Senegal & 211 & 8,977 \\
Thailand & 7,400 & 190,568 \\
Tunisia & 1,459 & 30,080 \\
Turkey & 10,872 & 474,154 \\
Uganda & 461 & 9,463 \\
\hline
\end{tabular}

Source: www.sesrtcic.org 
Fig.1. Average FDI in selected OIC countries 2002-2008 (million dollars)

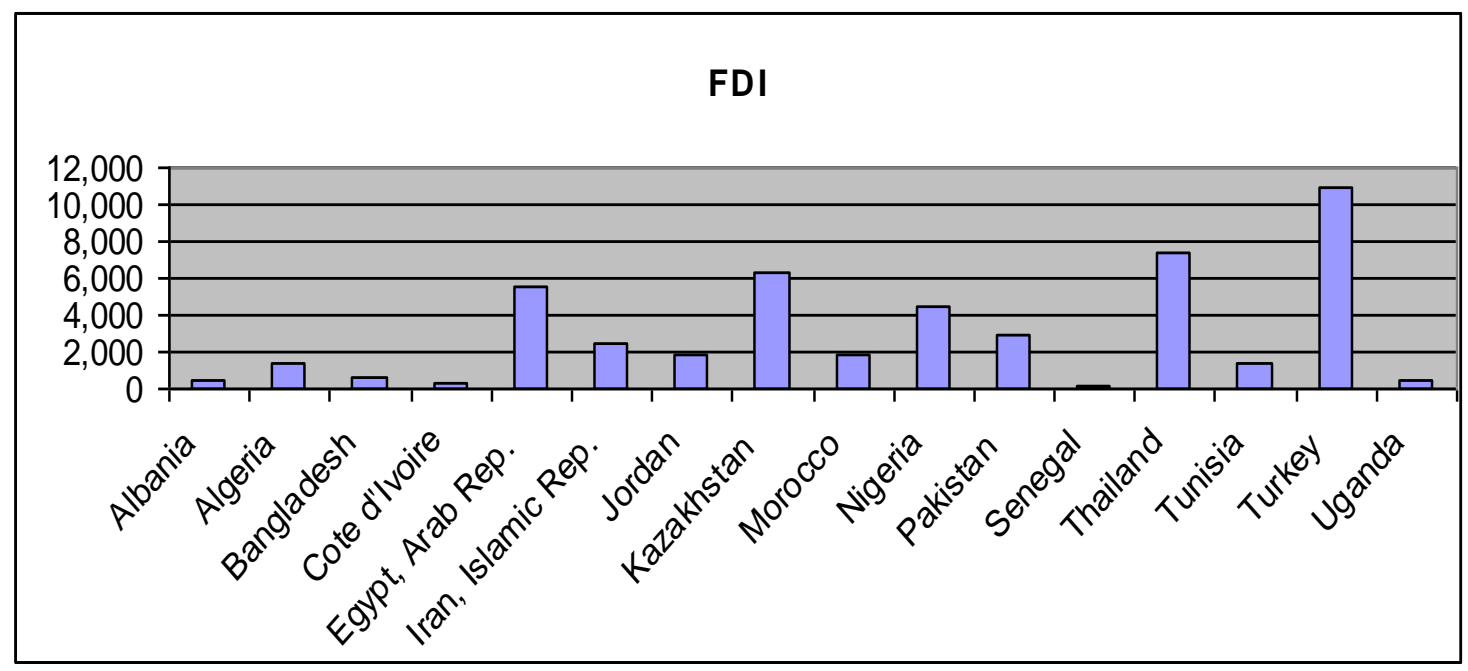

In this section, we detail the main empirical studies that attempt to estimate the Importance of the different determinants of FDI flows with panel data. In general a regression model of panel data is as follow:

$\mathrm{Y}_{\mathrm{it}}=\alpha_{\mathrm{it}}+\beta_{1} \mathrm{X}_{\mathrm{it}}+\beta_{2} \mathrm{X}_{2 \mathrm{it}}+\cdots+\mathrm{U}_{\mathrm{it}}$

$\mathrm{U}_{\mathrm{i}}=\mu_{\mathrm{i}}+\mathrm{V}_{\mathrm{it}}$

Where $\mathrm{E}\left(\mathrm{U}_{\mathrm{t}}\right)$ and have constant variance. $\mu_{\mathrm{t}}$ include Fixed Effects that show difference between individual, households or countries especial characteristic.

$V_{i t}$ is residual term that: $\quad V_{i t} \approx \operatorname{IID}\left(0, \delta_{W}^{2}\right)$

First we test heterogeneous between units by F-statistic. If null hypothesis is not accepted, we use panel data. Null hypothesis is:

$H_{0^{a} \mu_{1}}=\mu_{2}=\cdots=\mu_{n}=0$

$H_{0} \neq H_{1}$

$F=\frac{\frac{(\text { RRSS - URSS })}{(N-1)}}{\frac{U R S S}{\left(N T_{-} N \_K\right)}} \sim F\left[(N-1) \cdot\left(N T_{M_{K}}\right)\right]$

RRSS: Restrict Residual sum Squares

URSS: Unrestricted Residual sum Squares

$\mathrm{N}=$ numbers of units

$\mathrm{K}=$ numbers of Parameters

Then for choice between Fixed Effect (F.E) and Random Effect (R.E) models, we used Hausman Test:

$H=\left(b_{s}-B_{s}\right)\left(M_{1}-M_{0}\right)-1\left(b_{s}-B_{s}\right) \cdot x_{2}(r)$

$\mathrm{r}=$ number of parameters.

M1= covariance matrix for coefficients of F.E model (bs).

$\mathrm{M} 0=$ covariance matrix for coefficients of R.E model (bs).

The basic model is estimated on panel data for 16 OIC countries and the sample period is 2002-2008.

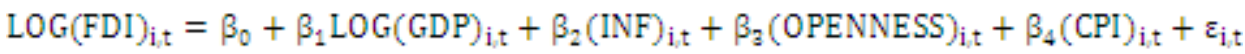


The estimation results using Eviews 6 are shown in table (3). As seen from Table (3), GDP and Openness have positive effect, Corruption has a negative and significance impact, Inflation has negative and insignificance effect on FDI inflows. In Hausman test null hypothesis show fixed effect. In accordance to above tests we run the regression whit fixed effect model (EGLS method). Table 3 presents the Panel EGLS (cross-section weights) regression results.

Table 3: Estimation of Model (2002-2008)

\begin{tabular}{|c|c|c|c|c|}
\hline Variable & Coefficient & Std. error & t-stat & Prob. \\
\hline LOG(GDP) & 1.169522 & 0.132914 & 8.799101 & 0 \\
\hline INF & -0.00877 & 0.009184 & -0.954668 & 0.3422 \\
\hline OPENNESS & 0.02615 & 0.005597 & 4.672159 & 0 \\
\hline CPI & 0.469289 & 0.140047 & 3.35094 & 0.0012 \\
\hline R-squared0 & & & & \\
\hline F-statistic $\quad 71.52$ & & & & \\
\hline Durbin-Watson stat 1.64 & & & & \\
\hline
\end{tabular}

\section{Conclusion and Recommendations}

In this study shows that the sign of corruption regressed on FDI is positive; it means that decreasing corruption (that is, CPI index increases) implies increasing FDI. We find that corruption perception does play a big role in investors' decision of where to invest. The more corrupt a country is perceived to be, the less the flows of FDI to OIC country. There is positive and significant relationship between foreign direct investment and gross domestic product, trade openness and inflation has negative and insignificant impact on FDI. Also, the explanatory power of the model is high; that is, it can explain \% 93 of factors determining foreign direct investment. Therefore, policies to eliminate corruption in these countries are suggested. Also, due to the fact that corruption is a multi-dimensional phenomenon then fighting against corruption is a very hard job. Therefore, the role of international corporations via International Organization such as The World Bank and Transparency International should be taken into account.

\section{References}

Abed, G. \& Davoodi, H. (2000). Corruption, Structural Reforms and Economic Performance in the Transition Economies. IMF Working Paper (132). International Monetary Fund.

Akcay, S. (2001). Is Corruption an Obstacle for Foreign Investors in developing Countries? Cross Country Evidence. Yapi Kredi Economic Review. 12 (2): 27-34.

Al-Sadig, A. (2009). The Effects of Corruption on FDI Inflows. Cato Journal. 29(2):267-294

Bardhan, P. (1997). Corruption and Development: A Review of Issues. Journal of Economic Literature. 35 (3): 1320-1346.

Habib, M. \& Zurawicki, L. (2002). Corruption and Foreign Direct Investment. Journal of International Business Studies. 33(2):291-307.

Houston, D. (2007). Can Corruption Ever Improve an Economy? Cato Journal, 27(3): 325-342.

Kardesler, E. (2009). The Impact of Corruption on FDI: An Application of Efficient Grease Hypothesis to EU Countries. Working Paper (9). Department of Economics, Izmir University of Economics, Izmir, Turkey

Kyung, J. H. (2009). Corruption and Foreign Direct Investment. Paper presented at the annual meeting of the International Studies. Available from http://www.allacademic.com/ meta/p100750_index.html.

Larrain, B. \& Tavares, J. (2004). Does Foreign Direct Investment Decrease Corruption? Cuadernos de Economia, 41: 217-230.

Mathur. A. (2007). Foreign Direct Investment, Corruption, and Democracy. Working Paper (135). May 15.

Smarzynska, B. \& Wei, S. (2002). Corruption and the Composition of Foreign Direct Investment: Firmlevel Evidence. NBER Working Paper No. 7969.

Swaleheen, M. \& Stansel, D. (2007). Economic Freedom, Corruption, and Economic Growth. Cato Journal, 27(3): 343-58. 
World Bank Indicators (2009). World Development Indicators 2009. Washington: World Bank.

Wei, S-J. (2000). Local Corruption and Global Capital Flows. Brookings Papers on Economic Activity, 2000: 303-354.

Zhou, Y. (2007). An empirical study of the relationship between corruption and FDI: with sample selection error correction. University of Birmingham. 